\title{
Arahan Pengembangan Kawasan Industri Kota Sorong Berbasis Green Industry
}

\author{
David Hehanussa $^{1 *}$, Arifuddin Akil ${ }^{1}$, Yashinta Kumala ${ }^{1}$ \\ ${ }^{1}$ Departemen Perencanaan Wilayah dan Kota, Fakultas Teknik, Universitas Hasanuddin \\ Jl. Poros Malino km. 6, Bontomarannu, Kabupaten Gowa, Sulawesi Selatan 92171 \\ *Email: david.hehanussa.dh@gmail.com
}

DOI: 10.25042/jpe.112019.02

\begin{abstract}
Abstrak
Sorong merupakan kota yang telah direncanakan sebagai pusat perekonomian yang akan melayani Kawasan Timur Indonesia. Hal ini membuat Kota Sorong direncanakan sebagai Kawasan Ekonomi Khusus (KEK) berdasarkan Rencana Tata Ruang Wilayah Nasional (RTRWN). Pada rencana tata ruang Kota Sorong telah direncanakan kawasan industri terpadu yang akan meningkatkan aktivitas perekonomian Kawasan Timur Indonesia. Pembangunan yang terjadi di Indonesia lebih bergantung pada aspek ekonomi tanpa melihat aspek lainnya sehingga perlunya perencanaan kawasan industri yang bukan hanya melibatkan aspek ekonomi, tetapi melibatkan aspek sosial dan aspek lingkungan. Tujuan Perencanaan ini ialah: 1) mengetahui peletakan kawasan industri saat ini ditinjau dari prinsip green industry; 2) melakukan evaluasi prinsip green industry khususnya dalam penentuan lokasi; 3) menyusun arahan pengembangan Kawasan Industri Sorong berdasarkan prinsip green industry. Penelitian ini menggunakan metode skoring, analisis spasial, dan analisis konseptual. Penelitian ini menunjukan bahwa bedasarkan prinsip location, penerapan prinsip memiliki total penerapan 75,6\% dan pada prinsip sustainabel site, wilayah lahan masuk klasifikasi "sangat sesuai".
\end{abstract}

\section{Abstract}

Direction for Development of Sorong City Industrial Estate Based on Green Industry. Sorong is a city that has been planned as an economic center that will serve Eastern Indonesia. This makes Sorong City planned as a Special Economic Zone (SEZ) based on the national spatial plan. The development that occurred in Indonesia is more dependent on economic aspects without looking at other aspects so that the need for industrial estate planning that not only involves economic aspects, but involves social aspects and environmental aspects. The purpose of this plan are: 1) know the current location of industrial estate in terms of the principles of green industry; 2) evaluate the principles of green industry, especially in determining the location; 3) draw up direction for the development of the industrial area of shoves based on the principles of green industry. This research uses scoring method, spatial analysis, and conceptual analysis. this study found that based on the principle of green industrial location, the application of these principles had a total application of $75.6 \%$ and on the principle of sustainable site, the area of land was classified as "very appropriate".

Kata Kunci: Industri hijau, kawasan pengembangan, kota Sorong

\section{Pendahuluan}

Sorong merupakan kota yang telah direncanakan sebagai pusat perekonomian yang akan melayani kawasan timur Indonesia. Hal ini membuat Sorong direncanakan sebagai Kawasan Ekonomi Khusus (KEK) berdasarkan Rencana Tata Ruang Wilayah Nasional (RTRWN). Pada rencana tata ruang Kota Sorong, telah direncanakan sebagai kawasan industri terpadu yang akan meningkatkan aktivitas perekonomian kawasan timur Indonesia.

Aktivitas industri memiliki peran dalam pertumbuhan ekonomi, tetapi di sisi lain juga mendorong terjadinya kerusakan lingkungan. Hal ini diperlukan suatu konsep yang menyelaraskan antara pertumbuhan ekonomi dan kelestarian lingkungan, yang dikenal dengan industri hijau (green industry). Penerapan industri hijau secara bertahap akan dapat membantu meningkatkan efisiensi, keuntungan, serta daya saing di pasar global. Pendekatan yang menerapkan prinsip-prinsip efisiensi dan pencegahan pencemaran, di satu sisi akan mampu mengurangi biaya produksi, sementara pada sisi lain kepentingan lingkungan juga terpenuhi. Realitas menunjukan bahwa dukungan terhadap pelaksanaan industri hijau dari beberapa perusahaan yang beroperasi di Indonesia belum cukup kuat.

Green industry merupakan kumpulan dari pabrik/industri yang mengaplikasikan teknologi 
produksi bersih, melakukan pemrosesan terhadap limbah industrinya dan/atau mengurangi emisi gas rumah kaca pada area dimana industri tersebut beroperasi [1]. Selain itu, terdapat pula konsep yang dikembangkan untuk mencapai manfaat lingkungan, ekonomi, dan sosial sebanyak mungkin. Terdapat berbagai macam kriteria yang salah satunya adalah produksi bersih [2]. Produksi bersih merupakan model pengelolaan lingkungan yang mengedepankan bagaimana agar setiap kegiatan industri yang dilakukan mempunyai efisiensi yang tinggi sehingga timbulan limbahnya dapat dicegah dan dikurangi [3]. Diterapkan produksi bersih maka industri akan diuntungkan, karena dapat menekan biaya produksi dan kinerja lingkungan menjadi lebih baik.

\section{Tinjauan Pustaka}

Kawasan industri adalah kawasan tempat pemusatan kegiatan industri pengolahan yang dilengkapi dengan prasarana, sarana dan fasilitas penunjang [4]. Industri hijau yang dalam proses produksinya mengutamakan upaya efisiensi dan efektivitas penggunaan sumber daya secara berkelanjutan sehingga mampu menyelaraskan pembangunan industri dengan kelestarian fungsi lingkungan hidup serta dapat memberi manfaat bagi masyarakat [5].

Adapun beberapa prinsip green industri yang digunakan yaitu: location, sustainable site, water efficiency, energy atmosphere, material resources, dan cleaner production [6]. Dari 6 prinsip yang ada, peneliti hanya menggunakan prinsip 1 dan prinsip 2 dikarenakan belum adanya pembangunan kawasan industri yang terjadi pada kawasan penelitian.

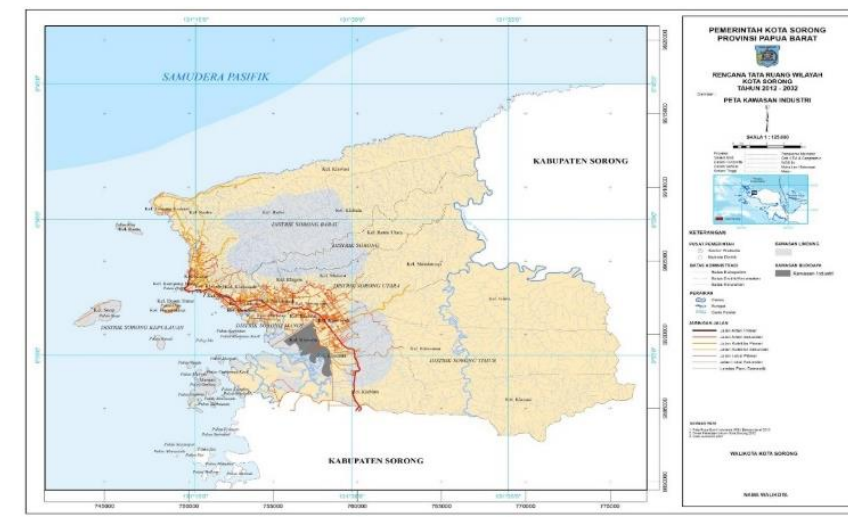

Gambar 1. Peta kota Sorong sebagai lokasi penelitian

\section{Metode Penelitian}

Penelitian ini menggunakan metode deskriptif komparatif dengan analisis skoring, spasial, dan konseptual. Lokasi penelitian dilakukan di Kota Sorong, lebih tepatnya pada Kawasan Industri Kota Sorong sesuai yang terdapat di lokasi RTRW. Lebih jelasnya lokasi penelitian dapat dilihat pada Gambar 1.

\section{Hasil dan Pembahasan}

\subsection{Identifikasi Kawasan Industri Kota Sorong}

Ditinjau dari rencana tata ruang wilayah Kota Sorong, Kawasan Industri Kota Sorong terletak pada Kelurahan Klawalu dan Klamana, dimana luas kawasan kelurahan tersebut dapat dilihat Gambar 2.

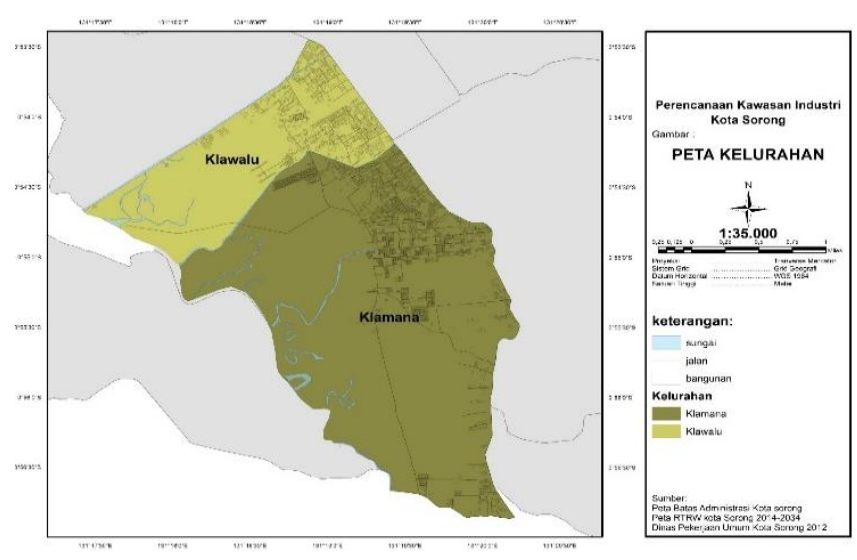

Gambar 2. Peta Kelurahan Klawalu dan Klamana sebagai lokasi penelitian

Penggunaan lahan pada Kelurahan Klawalu dan Klamana meliputi kawasan permukiman, mangrove, perkebunan, dan pertanian. Sebagian besar lahan lebih dioptimalkan untuk mangrove dan pertanian. Lebih jelasnya dapat dilihat pada Gambar 3.

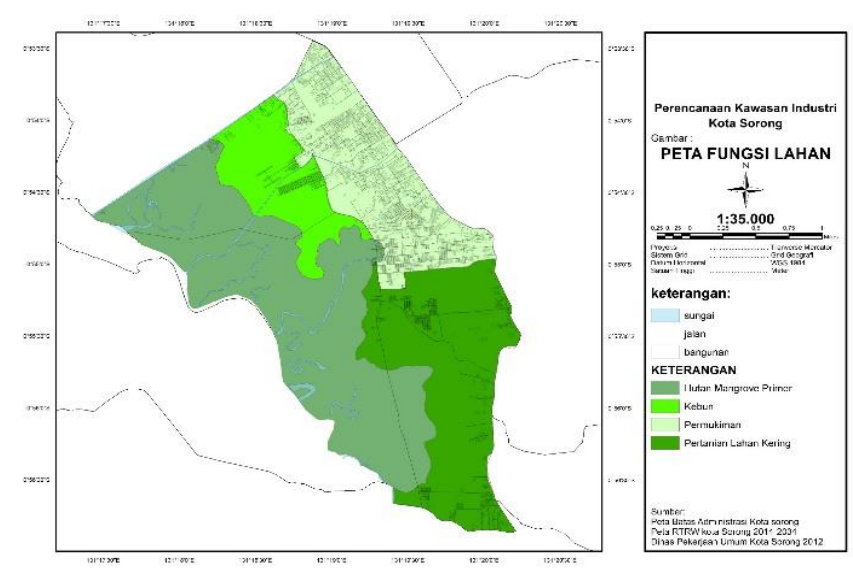

Gambar 3. Peta fungsi lahan 
Kondisi geologi pada Kelurahan Klawalu dan Klamana ialah terdapat 2 jenis batuan geologi yang tersebar di kawasan tersebut. 2 jenis batuan geologi tersebut yaitu endapan aluvium, litoral dan formasi klasaman. Endapan aluvium litoral terdiri dari beberapa batuan seperti batu lumpur, serpih, batu pasir, konglomerat, jarang batu gamping, koral ganggang, dan kasar di bagian utara. Selain itu jenis formasi klasaman terdiri dari pasir, kerikil, lumpur, sisa tumbuhan, gambut. Lebih jelasnya dapat dilihat pada Gambar 4.

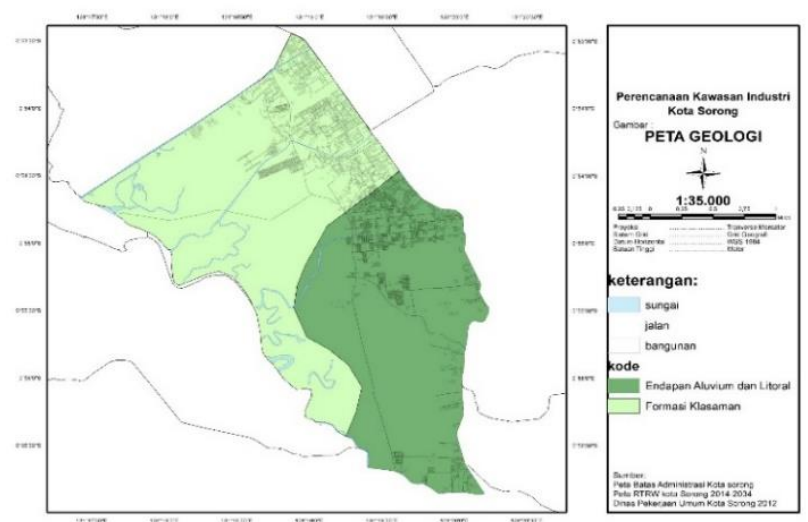

Gambar 4. Peta kondisi geologi

Kondisi topografi yang berada pada wilayah perencanaan memiliki kondisi rata-rata datar bila digambarkan dari keseluruhan wilayah. Hanya terdapat 2 angka kemiringan pada kawasan industri, dimana angka kemiringan 0$2 \%$ dan $2-8 \%$ pada kawasan tersebut. Lebih jelasnya dapat dilihat pada Gambar 5.

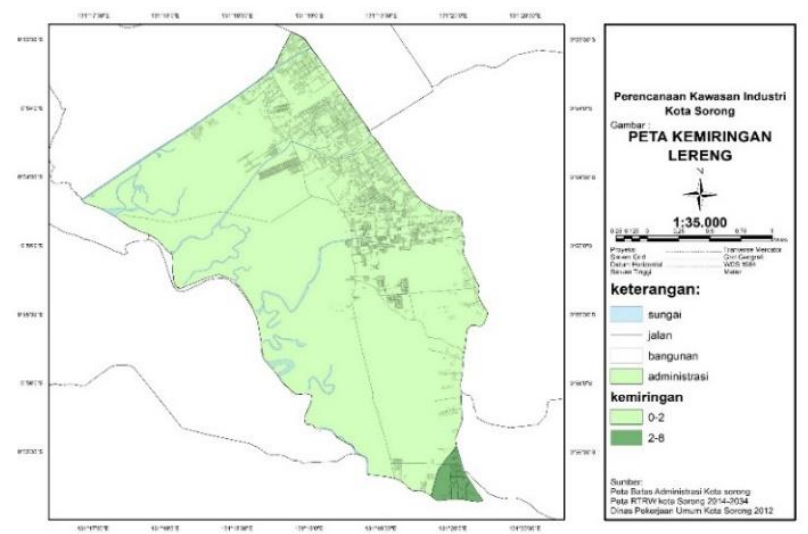

Gambar 5. Peta kemiringan lereng

Klasifikasi jalan terhadap jalan utama sangat menentukan kesesuaian lahan dalam penelitian kawasan industri, dikarenakan jalan sangat berpengaruh terhadap aksesibilitas dalam pelayanan kawasan industri, sehingga dari jalan yang ada pada eksisting melalui analisis buffer dan analisis skoring, maka dapat ditentukan pelayanan jalan utama terhadap lokasi industri. Klasifikasi jalan yang digunakan oleh peneliti yang dapat dilihat pada Gambar 6 .

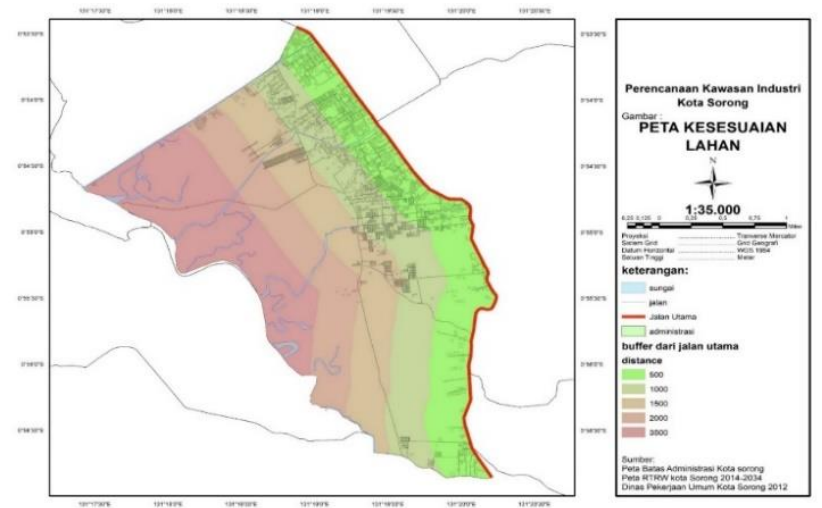

Gambar 6. Peta klasifikasi jarak terhadap jalan
utama

Klasifikasi jarak terhadap sungai merupakan komponen penting dalam penentuan kesesuaian lahan pada kawasan industri. Hal ini dikarenakan pentingnya kebutuhan sumber air dalam hal pelayanan kawasan industri dalam memudahkan aktivitas industri, sehingga terdapat klasifikasi jarak terhadap sungai pada kesesuaian lahan untuk menentukan lokasi. Dengan menggunakan analisis buffer dan analisis skoring, dapat dilihat penentuan klasifikasi kawasan industri dari daerah yang "sangat sesuai" hingga daerah yang "kurang sesuai". Adapun klasifikasi jarak sungai yang digunakan peneliti dalam menentukan skor dan identifikasi kesesuaian lahan yang dapat dilihat pada Gambar 7.

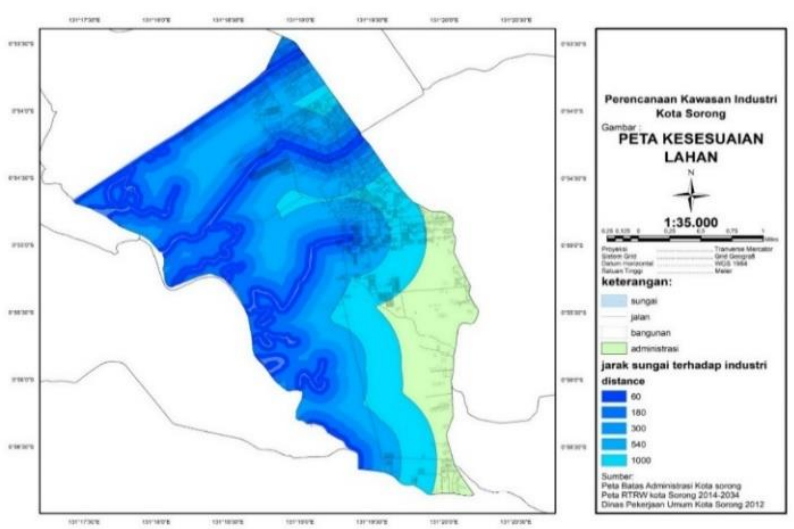

Gambar 7. Peta jarak terhadap sungai

Klasifikasi jarak permukiman dalam menentukan lokasi kawasan industri merupakan poin utama dalam hal kesesuaian lahan, 
dikarenakan dampak kawasan industri terhadap permukiman sangat rentan dalam masalah polusi, pencemaran, dan kebisingan. Jarak permukiman merupakan poin penting dalam penentuan kawasan industry, dengan menggunakan analisis buffer dan analisis skoring, dapat ditentukan penentuan kelas kawasan dan klasifikasi lahan terhadap permukiman di kawasan penelitian industri. Klasifikasi kawasan jarak permukiman yang digunakan peneliti yang dapat dilihat pada Gambar 8.

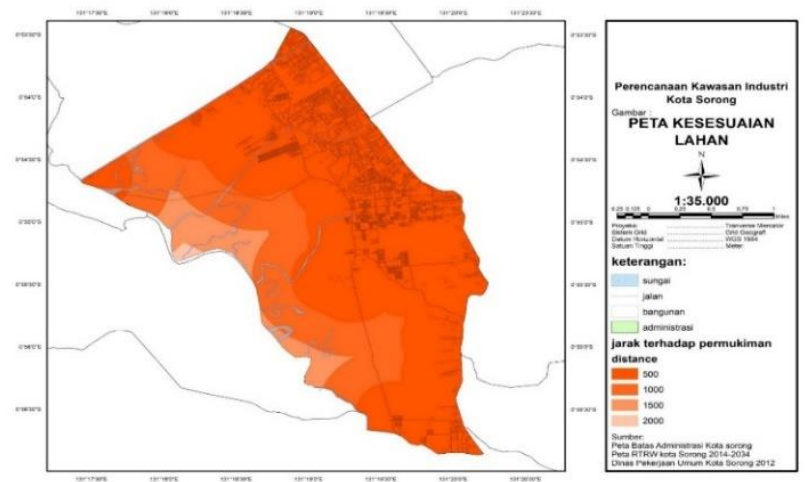

Gambar 8. Jarak terhadap permukiman

Dapat dilihat bahwa kondisi eksisting daerah rawan banjir berada dekat dengan kawasan industri. Dapat di identifikasi daerah banjir terhadap kesesuaian lahan kawasan industri, dengan menggunakan analisis buffer terhadap masing-masing kelas jarak terhadap banjir, maka dapat diketahui luasan dan skor yang didapatkan pada masing-masing kawasan. Hasil analisis buffer lebih jelasnya dapat dilihat pada Gambar 9.

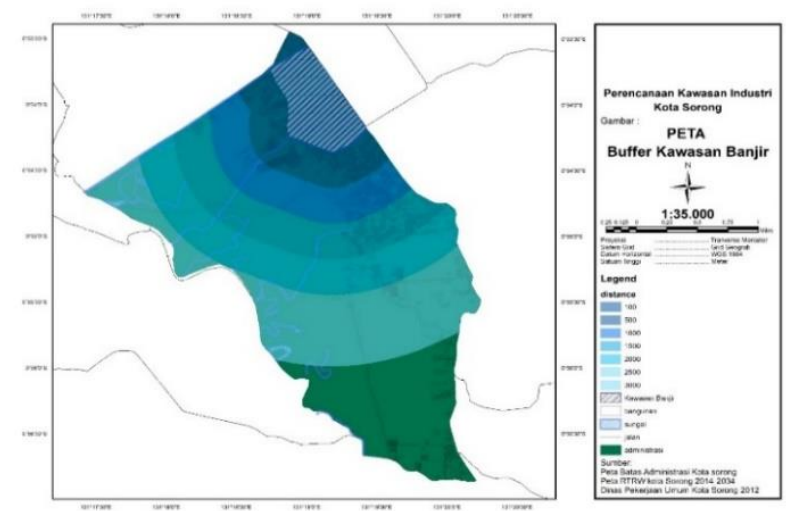

Gambar 9. Analisis jarak terhadap banjir

Ketidakpastian mengenai pelayanan energi listrik pada wilayah kawasan industri akan membuat pemerintah setempat dan pihak yang berwenang mengalami kesulitan. Dalam melakukan pelayanan terhadap energi listrik, perlunya klasifikasi dalam jarak pelayanan listrik terhadap kawasan industri, sehingga merupakan suatu acuan dalam kesesuaian lahan kawasan industri. Adapun standar klasifikasi pelayanan jaringan listrik yang digunakan peneliti sebagai acuan dalam mengidentifikasi kesesuaian lahan lokasi kawasan industri. Berikut merupakan peta analisis jaringan listrik pada Gambar 10.

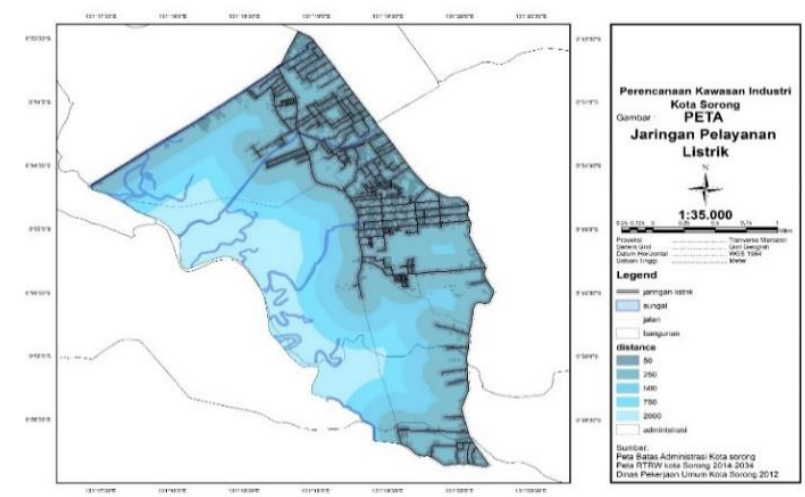

Gambar 10. Analisis jarak terhadap listrik

\subsection{Evaluasi Penerapan Green Industry pada Lokasi Penelitian}

Analisis pada prinsip location dilakukan untuk mengolah data hasil studi pustaka. Metode analisis yang digunakan adalah analisis gap secara deskriptif untuk mengetahui karakteristik dan kriteria pencapaian. Dalam penelitian ini, analisis gap digunakan untuk membandingkan kondisi ideal dari suatu lokasi industri berdasarkan literatur dan studi pustaka dengan kondisi aktual dari kawasan penelitian, sehingga dapat diketahui implementasi konsep industri yang ingin dicapai.

Penilaian dilakukan dengan asumsi bahwa seluruh variabel mempunyai bobot yang sama. Setiap kategori diasumsikan memiliki bobot $100 \%$, maka $100 \%$ tersebut dibagi rata sesuai banyaknya indikator yang diperoleh. Metode pembobotan ini juga digunakan dalam penilaian dengan metode Asian Green City Index [7]. Lebih jelasnya dapat dilihat pada Tabel 1 tentang bobot penilaian prinsip Location.

Adapun beberapa kriteria yang akan di ukur dalam hal kesesuaian lokasi kawasan industri, kriteria-kriteria tersebut ialah kebijakan, fisik lingkungan, konektivitas ekonomi, infrastruktur, bahan mentah, tenaga kerja, dan pasar/pemasaran. Dari hasil skoring terhadap kriteria kebijakan maka dimasukan hasil skoring 
terhadap evaluasi kebijakan yang ada sehingga didapatkan analisis skoring pada Tabel 2 .

Tabel 1. Bobot penilaian prinsip location

\begin{tabular}{clcc}
\hline $\begin{array}{c}\text { Aspek } \\
\text { Penilaian }\end{array}$ & Kriteria Penilaian & $\begin{array}{c}\text { Presentase } \\
\text { Penerapan }\end{array}$ & $\begin{array}{c}\text { Total } \\
\text { Penerapan }\end{array}$ \\
\hline & Kebijakan & $14,2 \%$ & \\
& Fisik lingkungan & $14,2 \%$ & \\
Lokasi & Konektivitas & $14,2 \%$ & \\
Strategis & ekonomi & $14,2 \%$ & $100 \%$ \\
& Infrastruktur & $14,2 \%$ & \\
& Bahan mentah & $14,2 \%$ & \\
& Tenaga kerja & $14,2 \%$ & \\
& Pasar/pemasaran & & \\
\hline
\end{tabular}

Tabel 2. Bobot penilaian kebijakan

\begin{tabular}{|c|c|c|c|c|c|}
\hline \multirow{2}{*}{$\begin{array}{c}\text { Aspek } \\
\text { penilaian }\end{array}$} & \multirow{2}{*}{ Evaluasi } & Skor & Skor & Skor & Skor \\
\hline & & $\mathbf{0}$ & 1 & 2 & 3 \\
\hline Kebijakan & $\begin{array}{l}\text { Kawasan Industri } \\
\text { Kota Sorong telah } \\
\text { tercantum pada } \\
\text { RTRWN }\end{array}$ & & & & \\
\hline \multicolumn{2}{|c|}{ Nilai penerapan total } & \multicolumn{4}{|c|}{3} \\
\hline \multicolumn{2}{|c|}{ Nilai maksimal } & \multicolumn{4}{|c|}{3} \\
\hline \multicolumn{2}{|c|}{ Presentase penerapan } & \multicolumn{4}{|c|}{$14,2 \%$} \\
\hline
\end{tabular}

Kriteria berdasarkan fisik lingkungan lokasi strategis digunakan untuk dapat melihat kesiapan wilayah lokasi strategis dari aspek spasial yaitu kejelasan wilayah administrasi, lokasi, dan kondisi lingkungan yang mendukung. Lokasi strategis juga perlu didukung dengan kesiapan menghadapi bencana yang mungkin dapat terjadi. Peneliti mengambil 4 Skor dan memiliki keterangan dari masing-masing skor, sehingga dapat di nilai terhadap penelitian Kawasan Industri Kota Sorong pada penerapan kajian dampak lingkungan dapat dilihat pada Tabel 3.

Tabel 3. Bobot penilaian fisik lingkungan

\begin{tabular}{|c|c|c|c|c|c|}
\hline \multirow{2}{*}{$\begin{array}{c}\text { Aspek } \\
\text { penilaian }\end{array}$} & \multirow{2}{*}{ Evaluasi } & Skor & Skor & Skor & Skor \\
\hline & & $\mathbf{0}$ & 1 & 2 & 3 \\
\hline $\begin{array}{l}\text { Fisik } \\
\text { lingkungan }\end{array}$ & $\begin{array}{l}\text { Tidak terdapat } \\
\text { kajian } \\
\text { lingkungan }\end{array}$ & $\sqrt{ }$ & & & \\
\hline \multicolumn{2}{|c|}{ Nilai penerapan total } & \multicolumn{4}{|c|}{0} \\
\hline \multicolumn{2}{|c|}{ Nilai maksimal } & \multicolumn{4}{|c|}{3} \\
\hline \multicolumn{2}{|c|}{ Presentase penerapan } & \multicolumn{4}{|c|}{$0 \%$} \\
\hline
\end{tabular}

Kriteria konektivitas ekonomi merupakan keterkaitan secara ekonomi antara suatu pusat pertumbuhan dengan pertumbuhan lainnya. Penekanan pada kriteria mengenai perekonomian menunjukkan kepentingan di dalam lokasi strategis maupun kontribusi lokasi strategis terhadap nasional. Kriteria-kriteria berikut ini didapatkan dari tinjauan literatur terkait pengembangan wilayah, studi yang dilakukan oleh European Spatial Development Perspectivel ESDP (1993) [8] dan kondisi perekonomian wilayah. Dapat dinilai aspekaspek penelitian Kawasan Industri Kota Sorong terhadap konektivitas perekonomian pada Tabel 4.

\section{Tabel 4. Hasil penilaian ekonomi}

\begin{tabular}{|c|c|c|c|c|c|}
\hline \multirow{2}{*}{$\begin{array}{c}\text { Aspek } \\
\text { penilaian }\end{array}$} & \multirow{2}{*}{ Evaluasi } & Skor & Skor & Skor & Skor \\
\hline & & $\mathbf{0}$ & 1 & 2 & 3 \\
\hline & Memiliki & & & & \\
\hline $\begin{array}{l}\text { Konektivitas } \\
\text { ekonomi }\end{array}$ & $\begin{array}{l}\text { kontribusi pada } \\
\text { ekonomi lokal } \\
\text { dan regional }\end{array}$ & & & $\checkmark$ & \\
\hline Nilai penerap & an total & & & 2 & \\
\hline Nilai maksim & & & & 3 & \\
\hline Presentase pe & nerapan & & & $\%$ & \\
\hline
\end{tabular}

Kriteria infrastruktur berdasarkan aksesbilitas terhadap lokasi strategis dan ketersediaan infrastruktur yang mendukung kegiatan di dalamnya, penekanan pada kriteria ini mengenai aksesbilitas dan infrastruktur pendukung. Kriteria-kriteria berikut ini didapatkan dari tinjauan literatur terkait infrastruktur, transportasi dan kebijakan. Peneliti mengambil 4 skor dan memiliki keterangan dari masing-masing skor, sehingga dapat di nilai aspek-aspek terhadap penelitian Kawasan Industri Kota Sorong pada penilaian infrastruktur pada Table 5.

Tabel 5. Hasil penilaian infrastruktur

\begin{tabular}{|c|c|c|c|c|c|}
\hline \multirow{2}{*}{$\begin{array}{c}\text { Aspek } \\
\text { penilaian }\end{array}$} & \multirow{2}{*}{ Evaluasi } & Skor & Skor & Skor & Skor \\
\hline & & $\mathbf{0}$ & 1 & 2 & 3 \\
\hline $\begin{array}{l}\text { Aksesibilitas } \\
\text { dan } \\
\text { infrasturktur }\end{array}$ & $\begin{array}{l}\text { Didukung } \\
\text { dengan } \\
\text { pelabuhan, } \\
\text { bandar udara, } \\
\text { jaringan jalan } \\
\text { utama, listrik } \\
\text { dan } \\
\text { telekomunikasi }\end{array}$ & & & & \\
\hline \multicolumn{2}{|c|}{ Nilai penerapan total } & \multicolumn{4}{|c|}{3} \\
\hline \multicolumn{2}{|c|}{ Nilai maksimal } & \multicolumn{4}{|c|}{3} \\
\hline \multicolumn{2}{|c|}{ Presentase penerapan } & \multicolumn{4}{|c|}{$14,2 \%$} \\
\hline
\end{tabular}

Bahan mentah menjadi faktor penentu lokasi industri yang penting karena bahan mentah adalah bahan dasar dalam menghasilkan suatu barang atau produk. Suatu industri jelas tidak bisa menjalankan proses produksinya ketika tidak terdapat bahan mentah. Adapun kriteria yang dicapai dalam penentuan bahan mentah lokasi industri yang dapat dilihat pada Tabel 6 . 
Tabel 6. Hasil penilaian bahan mentah

\begin{tabular}{|c|c|c|c|c|c|}
\hline \multirow{2}{*}{$\begin{array}{c}\text { Aspek } \\
\text { penilaian }\end{array}$} & \multirow{2}{*}{ Evaluasi } & Skor & Skor & Skor & Skor \\
\hline & & 0 & 1 & 2 & 3 \\
\hline & Memiliki & & & & \\
\hline & ketersediaan & & & & \\
\hline & bahan mentah & & & & \\
\hline Bahan & yang cukup & & & & \\
\hline mentah & besar dan berada & & & & \\
\hline & dekat dengan & & & & \\
\hline & lokasi kawasan & & & & \\
\hline & industri. & & & & \\
\hline Nilai pener & an total & & & & \\
\hline Nilai maksi & & & & & \\
\hline Presentase & nerapan & & & $\%$ & \\
\hline
\end{tabular}

Perlunya lokasi yang dekat terhadap lokasi industri dan pasar bertujuan untuk menemukan pola lokasi industri yang strategis. Pasar sebagai komponen yang sangat penting dalam mempertimbangkan lokasi industri, sebab pasar sebagai sarana untuk memasarkan atau menjual produk yang dihasilkan. Lokasi pasar ada kaitannya dengan lokasi pemukiman atau pusat penduduk, karena pada hakekatnya pasar adalah tempat untuk memenuhi semua kebutuhan hidup penduduk melalui transaksi jual beli. Lokasi pasar biasanya terletak di lokasi yang strategis dan mudah dijangkau oleh masyarakat. Adapun skor yang digunakan dalam jarak pelayanan pasar pada Tabel 7 .

Tabel 7. Hasil penilaian pemasaran

\begin{tabular}{|c|c|c|c|c|c|}
\hline \multirow{2}{*}{$\begin{array}{c}\text { Aspek } \\
\text { penilaian }\end{array}$} & \multirow{2}{*}{ Evaluasi } & Skor & Skor & Skor & Skor \\
\hline & & $\mathbf{0}$ & 1 & 2 & 3 \\
\hline Pasar & $\begin{array}{l}\text { Jarak pelayanan } \\
\text { pasar yang ada } \\
\text { mencakup } \\
\text { kawasan } \\
\text { industri lebih } \\
\text { dari } 500 \text { meter }\end{array}$ & & & & $\sqrt{ }$ \\
\hline \multicolumn{2}{|c|}{ Nilai penerapan total } & \multicolumn{4}{|c|}{3} \\
\hline \multicolumn{2}{|c|}{ Nilai maksimal } & \multicolumn{4}{|c|}{3} \\
\hline \multicolumn{2}{|c|}{ Presentase penerapan } & \multicolumn{4}{|c|}{$14,2 \%$} \\
\hline
\end{tabular}

Industri yang akan dibangun pada Kawasan Industri Kota Sorong ialah 2 jenis industri besar. Klasifikasi industri berdasarkan tenaga kerja, industri besar yaitu industri dengan jumlah tenaga kerja lebih dari 100 orang. Tenaga kerja dilihat dari tingkat pengangguran yang berada pada kawasan tersebut, khususnya pada pengangguran terbuka, sehingga didapatkan penilaian pada Tabel 8 .
Tabel 8. Hasil penilaian tenaga kerja

\begin{tabular}{|c|c|c|c|c|c|}
\hline \multirow{2}{*}{$\begin{array}{c}\text { Aspek } \\
\text { penilaian }\end{array}$} & \multirow{2}{*}{ Evaluasi } & Skor & Skor & Skor & Skor \\
\hline & & $\mathbf{0}$ & 1 & 2 & 3 \\
\hline $\begin{array}{l}\text { Tenaga } \\
\text { kerja }\end{array}$ & $\begin{array}{l}\text { Tingkat } \\
\text { pengangguran } \\
200-300 \text { orang } \\
\text { khususnya yang } \\
\text { memiliki } \\
\text { pendidikan } \\
\text { tertinggi skala } \\
\text { Universitas }\end{array}$ & & & $\sqrt{ }$ & \\
\hline Nilai pener & pan total & & & & \\
\hline Nilai maks & & & & & \\
\hline Presentase & enerapan & & & & \\
\hline
\end{tabular}

Kriteria penilaian memiliki bobot yang sama. Seluruh kriteria penilaian diasumsikan memiliki total bobot $100 \%$, maka total penerapan tersebut dibagi rata sesuai banyaknya kriteria penilaian sehingga masing-masing kriteria penilaian memiliki kriteria penilaian sebesar 14,2\%. Dari hasil analisis pada pembahasan, didapatkan presentase penerapan dari masing-masing kriteria. Seluruh presentase penerapan akan di jumlahkan dan akan diketahui hasil dari total penerapan prinsip location. Lebih jelasnya dapat dilihat pada Tabel 9.

Tabel 9. Presentase penerapan lokasi strategis

\begin{tabular}{llcc}
\hline $\begin{array}{c}\text { Aspek } \\
\text { penilaian }\end{array}$ & \multicolumn{1}{c}{$\begin{array}{c}\text { Kriteria } \\
\text { Penilaian }\end{array}$} & $\begin{array}{c}\text { Presentase } \\
\text { Penerapan }\end{array}$ & $\begin{array}{c}\text { Total } \\
\text { Penerapan }\end{array}$ \\
\hline & Kebijakan & $14,2 \%$ & \\
& Fisik lingkungan & $0 \%$ & \\
& Konektivitas & $9,4 \%$ & \\
Lokasi & ekonomi & $14,2 \%$ & $75,6 \%$ \\
strategis & Infrastruktur & $14,2 \%$ & \\
& Bahan mentah & $9,4 \%$ & \\
& Tenaga kerja & $14,2 \%$ & \\
\hline
\end{tabular}

Dari hasil presentase penerapan lokasi strategis, maka dapat disimpulkan bahwa seluruh total penerapan lokasi strategis memiliki total penerapan keseluruhan sebesar $75,6 \%$. Hal ini dikarenakan masih terdapat beberapa aspek yang kurang dalam suatu kriteria penilaian yang telah diatur.

Tabel 10. Klasifikasi kesesuaian lahan

\begin{tabular}{ll}
\hline Klasifikasi & Skor \\
\hline Sangat sesuai & 5 \\
Sesuai & 4 \\
Cukup sesuai & 3 \\
Kurang sesuai & 2 \\
Tidak sesuai & 1 \\
\hline
\end{tabular}


Pada evaluasi prinsip sustainable site, analisis yang digunakan ialah analisis kesesuaian lahan dengan menggunakan proses overlay. Proses overlay melalui Sistem Informasi Geograis (SIG) terhadap peta kesesuaian lahan Industri berfungsi untuk menentukan kesesuaian lahan lokasi industri. berdasarkan parameter kriteria pemilihan lahan, kawasan Industri terdiri 5 parameter, dimana parameter tersebut adalah "sangat sesuai", "sesuai", "cukup sesuai", "kurang sesuai" dan "tidak sesuai". Parameter kesesuaian lahan dapat dilihat pada Tabel 10.

Dari hasil analisis overlay, diperoleh bahwa wilayah Kawasan Industri lebih dominan masuk kedalam daftar klasifikasi "sangat sesuai" dikarenakan pada peta analisis kesesuaian lahan, Kawasan dengan klasifikasi "sangat sesuai" lebih dominan pada Kawasan penelitian. klasifikasi "sesuai" dan "cukup sesuai" masuk kedalam kawasan yang cukup dominan. Berdasarkan analisis overlay dapat disimpulkan bahwa, sebagian besar kesesuaian lahan pada Kawasan Industri Kota Sorong tergolong masuk ke dalam klasifikasi "sangat sesuai" dan memiliki skor 4. Untuk lebih jelasnya, peta hasil analisis overlay kesesuaian lahan kawasan industri dapat dilihat pada Gambar 11.

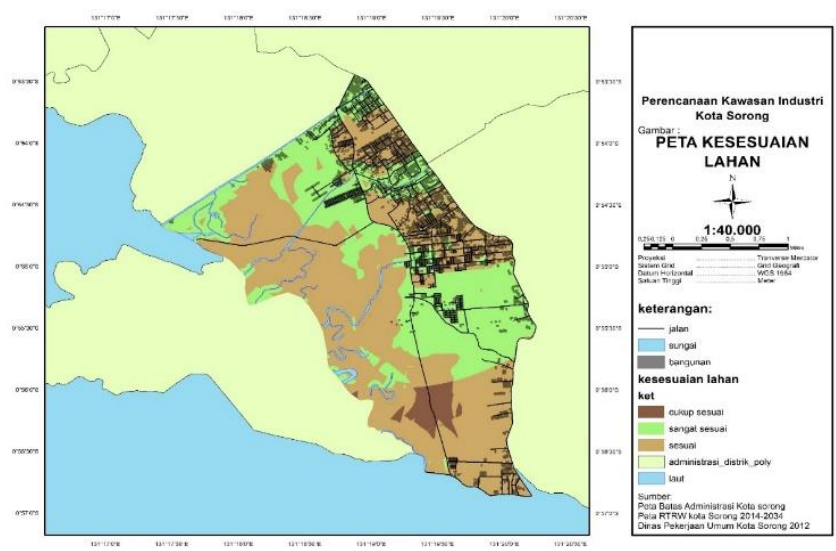

Gambar 11. Peta analisis kesesuaian lahan
4.3. Arahan Pengembangan Kawasan menurut Prinsip Green Industry

Dalam menentukan aspek arahan pengembangan kawasan, setiap aspek ditinjau dari hasil analisis yang ada. Berdasarkan kharakteristik lahan kawasan industri dan evaluasi komponen Green industry. Setiap aspek ditinjau dari skala prioritas sehingga adanya prioritas utama dalam menentukan prioritas masing-masing kriteria. Adapun pembagian prinsip, yaitu prinsip sustainable site dan prinsip location.

Pada prinsip sustainable site ditentukan berdasarkan presentase performa, dimana presentase performa lahan kawasan industri ialah "sangat sesuai", "sesuai", "cukup sesuai", "kurang sesuai", dan "tidak sesuai". Berdasarkan performa lahan maka dibagi menjadi 5 indikator skala prioritas sesuai dengan jumlah presentase performa pada Tabel 11.

Tabel 11. Skala prioritas kawasan

\begin{tabular}{cc}
\hline Skala prioritas & Presentase performa \\
\hline Prioritas 1 & Sangat sesuai \\
Prioritas 2 & Sesuai \\
Prioritas 3 & Cukup sesuai \\
Prioritas 4 & Kurang sesuai \\
Tidak prioritas & Tidak sesuai \\
\hline
\end{tabular}

Arahan pengembangan prinsip lokasi berdasarkan pada analisis lokasi yang telah dibahas didapatkan hasil evaluasi aspek penilaian lokasi dari masing-masing kriteria. Lebih jelasnya dapat dilihat pada Tabel 12 .

Berdasarkan hasil dari overlay pada analisis kesesuaian lahan, maka didapat beberapa indikator presentase performa dilihat dari kawasan lahan itu sendiri. Adanya presentase performa membuat skala prioritas dapat ditentukan dari tiap presentase performa. Presentase performa dapat dilihat pada Tabel 13.

Tabel 12. Skala prioritas kawasan

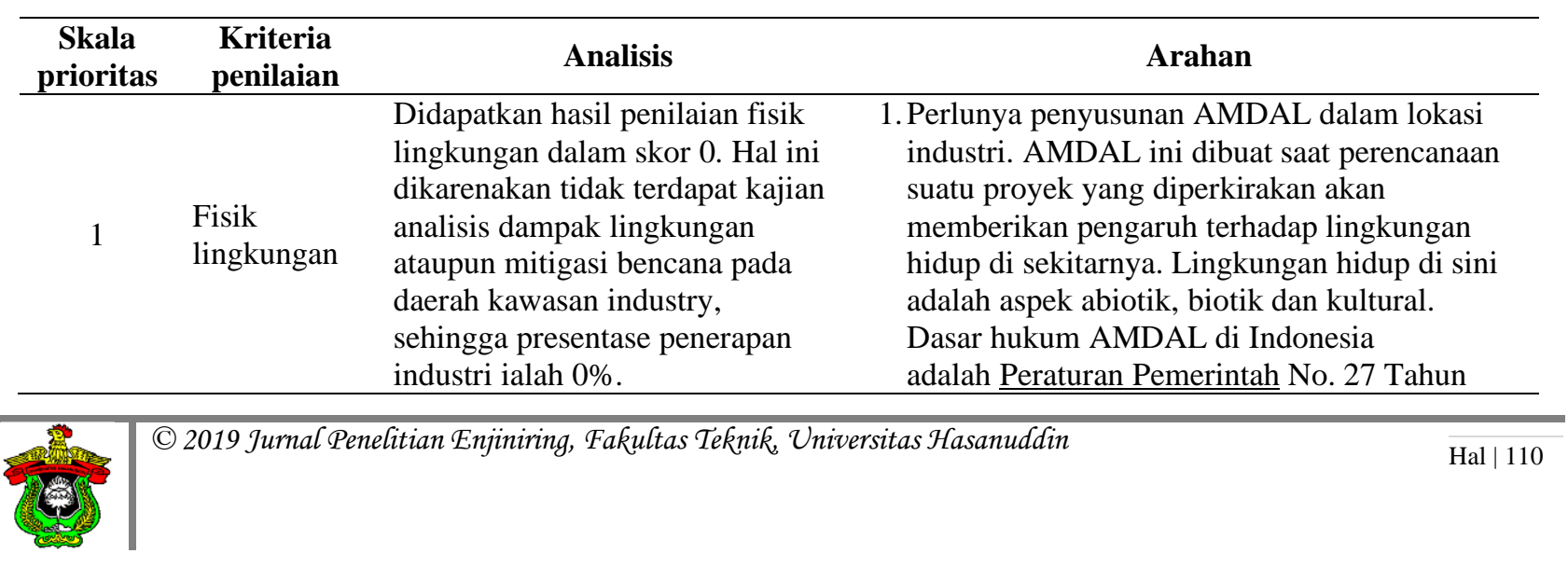


2012 tentang "Izin Lingkungan Hidup” yang merupakan pengganti PP 27 Tahun 1999 tentang Amdal.

2. Perlunya kajian mitigasi bencana dalam perencanaan kawasan industri untuk meminimalisir kerusakan yang ada.

1.Pembangunan sektor industri diharapkan mampu memberikan kontribusi yang besar terhadap pembangunan nasional baik dari aspek ekonomi, sosial, budaya maupun politik. Di lain pihak pembangunan ekonomi,

Kawasan industri yang direncanakan hanya melayani Kawasan Timur Indonesia, Konektivitas dikarenakan tidak adanya daerah ekonomi industri khususnya pada kawasan Timur Indonesia. sosial, budaya dan politik berpengaruh pada pembangunan industri.

2. UNIDO (2012) yang menyatakan bahwa kawasan industri bertujuan untuk mendorong pertumbuhan ekonomi dan lapangan kerja baik di tingkat nasional, regional, maupun tingkat lokal, menarik investasi asing, dan memacu perkembangan sektor industri.

Perlunya tenaga kerja yang memiliki jenjang pendidikan akhir universitas dikarenakan industri besar merupakan industri yang memiliki tenaga kerja minimal 100 orang pengangguran di Kota Sorong hanya 200-300 orang pada skala Universitas.

Tabel 13. Presentase performa lahan

\begin{tabular}{cc}
\hline Skala prioritas & Presentase performa \\
\hline Prioritas 1 & Sangat sesuai \\
Prioritas 2 & Sesuai \\
Prioritas 3 & Cukup sesuai \\
Prioritas 4 & Kurang sesuai \\
Tidak prioritas & Tidak sesuai \\
\hline
\end{tabular}

Dari skala prioritas tersebut jika disesuaikan dengan hasil analisis maka didapatkan hasil presentase performa sebagai berikut.

Tabel 14. Skala prioritas kawasan eksisting

\begin{tabular}{|c|c|c|c|}
\hline Skala Prioritas & $\begin{array}{l}\text { Presentase } \\
\text { Performa }\end{array}$ & Luas & Presentase \\
\hline Prioritas 1 & $\begin{array}{l}\text { Sangat } \\
\text { sesuai }\end{array}$ & $817,83 \mathrm{Ha}$ & $54,19 \%$ \\
\hline Prioritas 2 & Sesuai & $369,77 \mathrm{Ha}$ & $24,48 \%$ \\
\hline Prioritas 3 & $\begin{array}{l}\text { Cukup } \\
\text { sesuai }\end{array}$ & $320,24 \mathrm{Ha}$ & $21,20 \%$ \\
\hline Prioritas 4 & $\begin{array}{l}\text { Kurang } \\
\text { sesuai }\end{array}$ & 0,97 Ha & $0,06 \%$ \\
\hline Tidak prioritas & Tidak sesuai & 1,14 Ha & $0,07 \%$ \\
\hline \multicolumn{2}{|c|}{ Total keseluruhan } & $\begin{array}{c}1.509,95 \\
\mathrm{Ha}\end{array}$ & $100 \%$ \\
\hline
\end{tabular}

Dari tabel diatas dapat dilihat bahwa prioritas pertama terdapat pada presentase performa "sangat sesuai", dimana pada lahan prioritas lahan "sangat sesuai" seluas 362,94 Ha. Lahan tersebut merupakan 24,03\% dari luas lahan Penelitian Kawasan Industri. Setelah itu pada skala prioritas 2 ada pada presentase performa "sesuai", skala prioritas 2 merupakan skala prioritas lahan terluas diantara lahan presentase performa lainnya. Pada skala prioritas 2 memiliki luas lahan 834,07 Ha. Luasan lahan tersebut melebihi setengah dari luas kawasan industri seluruhnya dikarenakan jika dilihat pada presentase luas kawasan prioritas 2, luas lahan prioritas 2 sebesar $55,23 \%$.

Setelah itu pada luas lahan prioritas 3, dimana presentase performa cukup sesuai pada lahan Kawasan Industri memiliki luas sebesar 321,83 Ha. Luas kawasan tersebut merupakan luas paling besar 3 dari antara skala prioritas lainnya dikarenakan presentase luas kawasan jika dibandingkan dengan kawasan seluruhnya sebesar $21,24 \%$. Skala prioritas lainnya dimana terdapat prioritas 4 dan lahan yang tidak diprioritaskan sebagai lahan Kawasan Industri merupakan susunan lahan yang memiliki luas terkecil jika dilihat pada tabel diatas. 


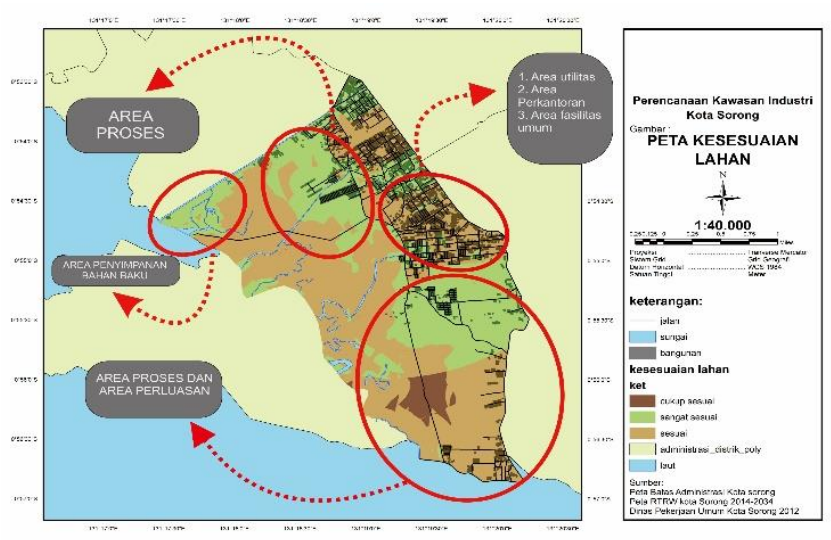

Gambar 12. Arahan Sustainable Site

\section{Kesimpulan}

Berdasarkan hasil penelitian dan pembahasan yang telah diuraikan, maka dalam penutup penulis akan memberikan kesimpulan sebagai berikut:

1. Kawasan Industri Kota Sorong berdasarkan karakteristik kondisi fisik lahan yang telah ditentukan oleh RTRW, adanya 3 karakteristik lahan yang dapat digunakan sebagai kawasan industri, 3 karakteristik lahan tersebut ialah "sangat sesuai", "sesuai", dan "cukup sesuai".

2. Berdasarkan prinsip green industry, pada prinsip location, penerapan prinsip tersebut memiliki total penerapan $75,6 \%$. Selain itu untuk penerapan prinsip sustainabel site, dari hasil analisis overlay bahwa wilayah kawasan industri lebih dominan masuk kedalam daftar klasifikasi "sangat sesuai" dikarenakan pada peta analisis kesesuaian lahan, kawasan dengan klasifikasi "sangat sesuai" lebih dominan pada kawasan tersebut.

3. Pada prinsip location, penerapan prinsip tersebut memiliki total penerapan $75,6 \%$.
Selain itu untuk penerapan prinsip sustainable site, dari hasil analisis overlay bahwa wilayah kawasan industri lebih dominan masuk kedalam daftar klasifikasi Sesuai dikarenakan pada peta analisis kesesuaian lahan, Kawasan dengan klasifikasi "sesuai" lebih dominan pada kawasan tersebut. setelah itu klasifikasi "sangat sesuai" dan "cukup sesuai" masuk kedalam kawasan yang dominan.

\section{Referensi}

[1] Fleig, Anja-Katrin. 2000. Eco-Industrial Parks, A Strategy towards Industrial Ecology in Developing and Newly Industrialised Country. Deutshce Gesellschaft fur Technische Zusammenarbeit (GTZ) GmbH. Eschborn.

[2] Lowe, Ernest A. 2001. Eco-industrial Park Handbook for Asian Developing Countries. www.indigodev.com diakses terakhir pada tanggal 26 Januari 2015.

[3] Purwanto. Andie T. Manajemen Lingkungan: Dulu, Sekarang, dan Masa Depan. andietri.tripod.com/jurnal/Manajemen_Lingkungan_ x.pdf (diakses 13 Desember 2016).

[4] Keputusan Presiden Republik Indonesia, 1989, Kawasan Industri, Keputusan Presiden Republik Indonesia Nomor 53 Tahun 1989.

[5] Keputusan Presiden Republik Indonesia, 1996, Kawasan Industri, Keputusan Presiden Republik Indonesia Nomor 41 Tahun 1996.

[6] [UNIDO] United Nations of Industrial Development Organization. 2012. Chrome Balance in Leather Processing, Hal. 3.

[7] Denig S. 2011. Asian Green Ciy Index: Assessing the Enviromental Performance of Asia's Major Cities. Munich: Siemens AG.

[8] [ESDP] European Spatial Development Perspective. 1993. Towards balanced and sustainable development of the territory of the European Union. 